\title{
O CUIDADO E SUAS REDES doença e diferença em instituiçóes de saúde indígena em Sáo Paulo
}

\section{Valéria Macedo}

E-mail: vmacedo@unifesp.br

(1) Professora associada no Departamento de Ciências Sociais e no Programa de Pós-Graduação em Ciências Sociais da Unifesp, Guarulhos/SP, Brasil.

DOI: $10.1590 / 3610602 / 2021$

\section{Introduçáo (alguns cuidados)}

Cuidado e humanização são palavras interseccionadas na etnologia ameríndia e, de modo distinto, em abordagens no campo da saúde. $\mathrm{O}$ exercício proposto neste artigo é estabelecer conexóes parciais (Strathern, 1991) ${ }^{1}$ entre esses campos como modo de fazer visíveis certas questóes concernentes à minha experiência etnográfica na Casai (Casa de Apoio à Saúde Indígena), na cidade de São Paulo. Via de regra, frequentei semanalmente a instituição para atividades de pesquisa e extensão universitária (Macedo et al., 2017) entre o segundo semestre de 2014 e o primeiro semestre de 2018 , quando pude conviver e conversar com funcionários, pacientes e acompanhantes, participar de reuniōes de diversas ordens, organizar sessóes de cinema indígena, oficinas

Artigo recebido em: 27/02/2020

Aprovado em: $31 / 07 / 2020$ e passeios na cidade, bem como acompanhar alguns pacientes em consultas, exames e outras intervençóes em hospitais e ambulatórios. Entre esses, o artigo estende o foco ao Hospital São Paulo, da Unifesp (Universidade Federal de São Paulo), que conta com o Ambulatório do Índio como instituição parceira da Casai-SP no acolhimento e acompanhamento de pacientes indígenas.

A Casai-SP é uma das 66 Casais $^{2}$ distribuídas em centros urbanos do país para receber indígenas que precisem afastar-se de suas comunidades para tratamento médico. Tais instituiçóes integram o Subsistema de Atenção à Saúde Indígena no Brasil, estabelecido pela chamada Lei Arouca ( ${ }^{\circ}$ 9.836-1999) em cumprimento à Constituição de 1988, que reconheceu o direito dos povos indígenas a políticas diferenciadas. Em seu desenho institucional, o Subsistema é composto por 34 Dseis (Distritos Sanitários Especiais Indígenas), cujas áreas de abrangência têm como critério proximidades culturais e relaçóes históricas entre 
povos indígenas em regióes contíguas. Vinculada ao Ministério da Saúde, a Secretaria Especial de Saúde Indígena (Sesai) atualmente é o órgão responsável pelo Subsistema, contando com uma gestão descentralizada em convênios com organizaçôes não-governamentais indígenas e não-indígenas. Cada Dsei é formado por pólos-base com equipes multiprofissionais de saúde dentro ou próximos às terras indígenas, conselhos locais e distritais (responsáveis pelo controle social dos serviços) e as Casais. Estas devem hospedar, prestar serviços de enfermagem e acompanhar o tratamento dos pacientes indígenas em hospitais do SUS (Sistema Único de Saúde) (Langdon e Garnelo, 2004; Dias da Silva, 2010; Gonçalves, 2011; Cruz e Guimarães, 2016).

Quando o diagnóstico ou o tratamento não é viável em hospitais dos municípios incidentes em um Dsei, o paciente pode ser enviado para complexos hospitalares mais equipados em cidades como São Paulo ou Brasília. Por essa razão, a Casai-SP, a despeito de ser vinculada ao Dsei Litoral-Sul, recebe indígenas de todas as regióes do país, que ali convivem por períodos variados - podendo ser dias, semanas ou meses, havendo ainda aqueles que retornam periodicamente - com equipes de enfermagem e outros funcionários. ${ }^{3}$ Para muitos indígenas, habitar provisoriamente esse espaço pleno de diferença intensifica a vulnerabilidade inerente ao adoecimento, em que o corpo é habitado por outros. Nos casos em que o corpo é desabitado, em razão do afastamento da alma e dispersão de componentes da pessoa, o afastamento dos parentes durante a estadia na Casai também estende para fora dos corpos o esgarçamento que o adoecimento produz em seu interior. ${ }^{4}$

Em meio à irredutível singularidade de suas experiências, estar sob cuidado dos brancos constitui um ponto convergente entre os indígenas de diferentes povos que vêm a São Paulo para tratamento biomédico. Ser alvo de cuidado implica estar sob o olhar - e, portanto, sob a consideração ou a intervenção - de outrem, mas implica também fazer-se visível a ele, mobilizá-lo de modos específicos, fazer com que ele faça. Este texto se volta para algumas relaçóes de cuidado em que pacientes indígenas e profissionais de saúde estão ativamente, e diferentemente, implicados.
Em artigo recente, Kelly e Matos (2019) destacam a centralidade do cuidado no universo relacional ameríndio como um modo de elicitação (no sentido de Strathern, 2006), em que aquele que sofre uma ação é tão ativo quanto aquele que age, posicionandose como a causa motivadora do agente. Os autores trazem à cena o cuidado em relaçóes de conjugalidade, filiação, xamanismo, maestria, chefia e patronagem, articulando etnografias junto a diferentes povos.

A seu turno, em sua etnografia em um hospital em Madang, na Melanésia, Street (2014) aborda a produção de corpos biológicos - por meio de dispositivos e intervenções biomédicas - como formas persuasivas pelas quais pacientes podem elicitar o cuidado dos médicos, fazendo-os reconhecer e combater a doença de um modo específico. Contudo, a precariedade dos equipamentos e condiçóes daquele hospital produz um lugar instável para a biomedicina, já que a eficácia desta depende de fazer a doença visível na forma adequada.

Entre os pacientes em Madang, elicitar esse olhar clínico não corresponde a incorporá-lo ou naturalizar o que ele faz visível. Não implica, portanto, compartilhar o que Foucault (1977) chamou regard médical (mais difundido na literatura em sua versão inglesa, clinical gaze). $\mathrm{O}$ autor reconhece o nascimento da clínica no início do século XIX como uma revolução epistêmica, a partir da qual corpos e doenças passam a ser apreendidos como realidades exteriores aos dispositivos e métodos científicos, os quais apenas os revelariam e combateriam. Sob esse olhar clinico, o exame dos tecidos do corpo ganha proeminência como ciência empírica e positiva. Assim, "o individuo posto em questão é menos a pessoa doente do que o fato patológico indefinidamente reprodutivel em todos os doentes igualmente afetados"(1977, p.110). Tal olhar foi se diversificando e complexificando ao longo da história da clínica, mas Good (1993) destaca que se tornar um médico ainda implica aprender a ver o corpo como um sistema biológico.

Críticas a essa visão vieram se avolumando desde a década de 1960, com a proposta de uma medicina humanizada, em que cuidado se torna uma expressãochave na consideração da subjetividade e de aspectos socioculturais do paciente, para além da dimensão estritamente biomédica. Tal inflexão também decorre 
de críticas acerca da tendência à fragmentação do corpo em diferentes especialidades médicas e a pouca atenção dos médicos a quaisquer aspectos que não digam respeito à parte concernente a sua respectiva especialidade, como se o olhar do especialista sobre a patologia dispensasse o que o paciente pode fazer visível em relação a ela (Goffman, 1974; Halpern, 2001; Deslandes, 2006).

No contexto brasileiro, debates acerca da medicina humanizada foram introduzidos no âmbito da chamada Reforma Sanitária, articulada em resistência ao regime militar nos anos 1970 e que culmina, após a Constituição de 1988, com a elaboração do SUS, a Lei Arouca e a Política Nacional de Humanização (Deslandes, 2006). Particularmente no que concerne a políticas no campo da saúde indígena, a humanização costuma ser vinculada à proteçáo e ao respeito a modos de viver, valores, práticas e conhecimentos indígenas relativos a processos de adoecimento e tratamento (Langdon e Garnelo, 2004, 2017; Dias da Silva, 2010; Novo, 2010).

Pautado pelo multiculturalismo (no sentido de Viveiros de Castro, 2002), o cuidado humanizado entre profissionais de saúde, via de regra, implica o reconhecimento da humanidade como fundamento biológico comum (recusando tipologias e hierarquias raciais) e das culturas como direito à diferença (desautorizando hierarquizaçóes culturais). Como horizonte normativo, o cuidado humanizado busca, assim, ampliar e matizar o olhar clinico, mas sem desestabilizar a divisão entre natureza e cultura como base epistêmica que o sustenta.

A seu turno, a antropologia vem aprendendo com os povos indígenas que cuidado e humanização podem estar diferentemente implicados. Como abordado na síntese teórica de Viveiros de Castro $(2002,2007)$ sobre o perspectivismo ameríndio, aquilo que se traduz por humano não é algo biologicamente dado, e sim relacional, de modo que se reconhecem como mutuamente humanos aqueles cujos corpos são feitos de incorporaçóes (de coisas, substâncias, pessoas, capacidades) e potências afectivas (no sentido de Spinoza, 2013[1677]) compartilhadas. Intervenções nos corpos por práticas de cuidado ao longo do ciclo de vida constroem o parentesco sobre um fundo primordial de diferenças. $\mathrm{O}$ adoecimento constitui um desarranjo nessas incorporaçóes, podendo incorrer num gradiente de desumanização em relaçáo aos parentes e no aparentamento, mesmo que reversível, com outras gentes (mortos, espíritos, animais, não-indígenas etc.). Daí a aquisição de capacidades xamânicas ser frequentemente associada a experiências de adoecimento, cuja instabilidade ontológica pode engendrar habilidades de trânsito e comunicação entre diferentes mundos e corpos.

Seja como construção do parentesco a partir de um fundo de diferença em socialidades indígenas, seja como consideração da diferença a partir de um fundo de igualdade em políticas de saúde, o cuidado como humanização traz à cena o imperativo de compor-se com outros. No campo da saúde, Mol (2008, p. 91) destaca como a doença faz visível a vulnerabilidade constitutiva dos corpos e propóe o cuidado como espaço heterotópico (no sentido de Foucault, 2013), marcado por sua alteridade, incompletude, contingência e por experimentaçôes que mobilizam diferentes conhecimentos, pessoas e materialidades.

Mol também busca deslocar a ênfase analítica na interpretação como lócus da diferença para as práticas como produtoras de diferença. A autora se volta para a multiplicidade de formas com que corpos e patologias ganham existência a depender dos dispositivos e práticas, e como o trabalho de coordenação dessa multiplicidade em instituições de saúde é necessário para que o corpo seja "mais do que um e menos do que muitos" (2002, p.55). Tais formas não dizem respeito a diferentes interpretaçōes ou representaçōes de uma realidade que lhes antecede ou é exterior, já que diferentes intervençóes e instrumentos fazem múltiplas realidades, trazendo à existência objetos múltiplos.

Em diálogo com esses e outros autores, o texto se volta para como corpos e doenças são feitos, desfeitos ou refeitos por meio de relaçôes de cuidado nessas instituiçôes de saúde indígena. A ideia não é contrastar diferentes concepçōes de cuidado, mas transitar por enredos em que essas diferenças trabalham juntas. Além desta longa introdução e de uma breve nota conclusiva, o artigo é composto por três seçôes, cada qual propondo incursóes etnográficas em dimensôes do cuidado associadas à humanizaçấo no campo da 
saúde e formalizadas em dinâmicas institucionais: 1) Acolhimento, centrando foco na familiarização (que inclui apreensóes e o deixar-se apreender) com espaços, pessoas, posiçóes e dinâmicas institucionais na Casai-SP; 2) Coordenação, abordando o cuidado como intervenção que realiza (enacts, no sentido de Mol, 2002) corpos e doenças, bem como o manejo de sua multiplicidade ontológica e políticas de visibilidade durante o tratamento; 3) Atenção, particularmente atenção diferenciada, voltando-se para a produçãoconceituação de vínculos, alteridades e alterações entre profissionais de saúde e pacientes ou acompanhantes indígenas, em processos de tradução mútua que engendram novas diferenças, vulnerabilidades e possibilidades de compor-se com outros.

Como dispositivos relacionais do cuidado, tais dimensóes são também chamadas tecnologias leves no campo da saúde (Merhy, 1997, p.136; Teixeira, 2003, p.94; Deslandes, 2006). Como aponta $\mathrm{Mol}$ (2008, p.5-6), estas tecnologias não devem ser consideradas em oposição ou à parte de outros dispositivos tecnológicos mobilizados no tratamento, já que o cuidado remete ao modo com que são articulados. Abordagens etnográficas trazem à cena a multiplicidade de engendramentos envolvendo esses dispositivos, de modo a matizar os horizontes normativos das políticas de saúde. Nesse sentido, Ayres pondera que, como horizontes, eles se deslocam à medida que os sujeitos se movem, de modo que a saúde humanizada constitui um devir (2006, p.51).

Este texto busca somar-se às poucas etnografias voltadas para Casais. Com exceção de Cruz e Guimarães (2016) e Guimarães e Rosa (2019), cujos trabalhos abordam a Casai-DF, etnografias junto a comunidades ou povos indígenas específicos incluíram relatos sobre Casais, mas não tinham a instituição como foco principal (por ex. Dias da Silva, 2010; Rosalen, 2008, 2017; Araújo, 2015). No que diz respeito à Casai-SP, Gonçalves (2011) fez trabalho de campo uma década antes de mim (2004-2005), mas é possível reconhecer muitas continuidades entre nossas experiências. $\mathrm{Na}$ área de psicologia, sua pesquisa também se voltou para a questão do cuidado, reconhecendo-o como espaço de fronteira entre diferentes universos culturais e a escuta do outro como modo de ocupar esse espaço na Casai. Caldeira
(2010) e Garfunkel (2010) também compartilharam reflexôes sobre sua atuação profissional na Casai-SP como antropóloga e psicóloga, respectivamente.

Para além das publicaçôes, comentários recorrentes de profissionais de saúde e indígenas de diferentes povos apontam a Casai-SP como uma das que mais se aproxima do horizonte do cuidado humanizado em comparação a outras Casais. Daí a relevância de uma aproximação etnográfica a esse espaço. Mas o desafio de convivência com pessoas de diferentes povos que ali estão de passagem, posto a profissionais e hóspedes na Casai-SP, também se coloca para quem faz trabalho de campo nessa instituição. Como metarreferência a essa configuração relacional, o texto toma o caminho arriscado de não centrar foco em um caso, tampouco em um povo ou grupo profissional. Transitando entre dinâmicas institucionais, materialidades, relatos e enredos, o exercício foi escrever sobre relaçóes de cuidado - nas quais também tomei parte - como uma composição de diferenças (Strathern, 1991, p.55).

\section{Acolhimento}

A chegada de qualquer paciente à Casai-SP é precedida pela chegada da doença que o trouxe. A estadia na instituição é possível mediante solicitação acompanhada de relatórios médicos e exames que sinalizam uma patologia ou descrevem sintomas e formas cuja multiplicidade ainda não foi coordenada a ponto de performar (Mol, 2002) $)^{5}$ uma doença reconhecível no repertório biomédico. Como a CasaiSP conta com apenas 40 leitos, incluindo pacientes e acompanhantes, tais vagas são bastante disputadas e o modo como a doença ganha forma nos documentos de solicitação da Casai ou polo-base de origem do paciente é fundamental para consegui-las.

Segundo levantamento de um funcionário da Casai-SP para o ano de 2016, dos 1.406 indígenas atendidos, 665 eram do povo Guarani, correspondendo a 47,3\% dos pacientes (Barbeiro, 2017, p.18). Entre aqueles que vêm de outros estados, a chegada a São Paulo, na maioria dos casos, se dá por avião - por vezes precedida por longos translados de ônibus, carro ou barco e horas de espera entre um trecho e outro. Um técnico de enfermagem da equipe da Casai busca o paciente e seu acompanhante - geralmente 
um parente - no aeroporto em São Paulo, dando início ao processo de acolhimento.

Figurando entre as tecnologias leves do cuidado no campo da saúde humanizada, o acolhimento incide na qualidade da interlocução entre paciente e cuidador (Teixeira, 2003; Ayres, 2006). Na Casai-SP, a recepção dos pacientes indígenas e seus acompanhantes costumava ser iniciada com a explicação sobre as regras de funcionamento da instituição, como o uso coletivo dos quartos, banheiros e do refeitório, horários das refeições, trocas de roupa de cama, serviço de lavanderia etc. Um dos técnicos ${ }^{6}$ disse-me que também buscava saber se havia restrição do paciente a alguma etnia, de modo a evitar problemas que já haviam tido quando pessoas de povos envolvidos em acusaçóes de feitiçaria eram postas no mesmo quarto, sobretudo no caso de comunidades alto-xinguanas.

A assistente social complementava o acolhimento iniciado pelo técnico aplicando um formulário de perguntas sobre a comunidade de origem do paciente $\mathrm{e}$ buscando aferir o quanto ele ou o acompanhante (se o paciente for criança ou tiver dificuldades no português ou outro constrangimento para expressar-se) compreende a doença ou o tratamento a ser feito. A formulação biomédica da doença era, portanto, tomada como realidade que podia ou não ser compreendida pelo paciente. $\mathrm{O}$ formulário visava, assim, dimensionar o quanto o paciente era ou poderia ser familiarizado com o tratamento e a instituição. Em razão da frequência com que eram desconsideradas, também eram destacadas algumas regras, como a proibição do uso de bebidas alcoólicas e saídas sem consultar a equipe de enfermagem. $\mathrm{O}$ modelo de entrevista dessa interlocução, em que se demanda respostas a serem anotadas pela profissional, muitas vezes rendia poucas palavras dos recém-chegados, mas iniciava o processo de apreender-se como paciente indígena na Casai-SP como aspecto central do acolhimento.

A familiarização com o espaço e as gentes que o habitam pode ser mais ou menos difícil, desejável ou evitada pelos pacientes, a depender de seu domínio do português, do histórico de contato com nãoindígenas, instituiçóes de saúde e cidades, bem como de propensóes pessoais ou da coletividade da qual se é parte, entre outros aspectos. Em diferentes modulaçóes, tal processo pode ser aproximado ao que Nunes (2013) relata a partir de incursões com os Karajá de Buridina pelos territórios das onças (a mata) e dos brancos (a cidade). Esses lugares estabilizam a perspectiva de seus habitantes, e adentrá-los demanda acessar essa perspectiva por meio de alteraçóes nos corpos, roupas, comportamentos, linguagens. Na Casai, o desafio é modular cuidados a que se estará sujeito, elicitando-os ou evitando-os, mas são inescapáveis os efeitos corpóreo-afectivos da comida, cheiros, ruídos, remédios, espaços, pessoas e dinâmicas institucionais, como também destacado em outros trabalhos sobre Casais ou hospitais (Garnelo, 2003; Gonçalves, 2011; Rosalen, 2008, 2017; Araújo, 2015; Martín, 2015; Guimarães e Rosa, 2019).

"Tudo quieto", "vazio", "parado". Esses são alguns comentários que ouvi de indígenas sobre suas impressóes quando chegaram na Casai. Como parte do acolhimento, o paciente e seu acompanhante costumam ser levados a conhecer o espaço pelo técnico que os buscou no aeroporto ou outro funcionário. Nos anos em que a frequentei, a Casai ficava numa antiga casa na Vila Monumento (próxima ao Parque do Ipiranga), tendo sido transferida para um edifício na mesma regiáo no final de 2018. Os recém-chegados comumente eram apresentados às duas salas do setor administrativo e à pequena enfermaria, então percorriam os dois quartos do térreo (com oito camas cada um) e os quatro quartos do segundo andar (que somavam 24 leitos). Nos dormitórios encontravam pessoas dormindo, vendo algo no celular, ouvindo rádio, trabalhando com fios e miçangas, absortas em seus pensamentos, entre outras atividades não raro marcadas por uma apatia por vezes advinda do adoecimento, mas também pelas poucas possibilidades de o que fazer.

$\mathrm{O}$ acolhimento podia seguir com a apresentação do refeitório coletivo, onde havia uma televisão quase sempre ligada. No quintal comumente havia algumas crianças brincando, enquanto adultos aproveitavam o sol nas cadeiras brancas de plástico espalhadas pelo chão cimentado, podendo ficar olhando por longos períodos para a avenida Ricardo Jafet e seu ininterrupto fluxo de carros, que provavelmente atrapalharia o sono dos recém-chegados. Nos dias de calor, os pernilongos também conturbavam as noites de muitos. Um Mehinaku contou-me que ficou muito 
assustado quando chegou à Casai e viu a parede ao lado de sua cama com numerosas manchinhas de sangue. Sonhou que alguém desconhecido bebia numa cuia e, ao perceber que era sangue, cuspia na parede. Quando associei as manchas à abundância de pernilongos, ele enfatizou que o sonho o tinha avisado de que aquele sangue de outros não era bom. A parede aparecia assim como uma metonímia daquele espaço, onde circulam substâncias de múltiplas proveniências e potências afectivas.

O sangue nas paredes era, contudo, uma exceção nas superfícies frias e facilmente limpáveis da casa, com seu chão de ardósia (no interior) ou de cimento (no quintal), mesas de fórmica, cadeiras de plástico, camas de ferro e colchóes impermeáveis. No inverno essas superfícies ficavam ainda mais frias, e um Munduruku contou que ficava recolhido na cama porque tinha receio do frio que vinha não só do piso, mas dos que estavam debaixo do chão. Outras características do espaço e das dinâmicas institucionais não raro imprimiam nos corpos esse recolhimento, além do corpo enfraquecido pelo adoecimento. Nessa direção, um senhor Kawaiwete disse que as pessoas que pareciam muito grandes no Xingu ficavam pequenininhas na Casai.

Nas aldeias, o adoecimento também costuma implicar recolhimento e vulnerabilidade, demandando cuidados de parentes e pajés, benzedores, raizeiras, entre outros especialistas xamânicos. Mas ser acolhido em uma instituição de saúde indígena de uma grande metrópole implica apreender-se sob a perspectiva dos brancos, sendo posicionado na condição de paciente indigena. De diferentes maneiras, pessoas enfatizam a posição de passividade em que se encontram e como ela incide em seus corpos, inclusive entre os acompanhantes. Cinco refeiçôes diárias são servidas prontas, por vezes com cheiros e formatos que alguns não reconhecem e sentem receio de comer. Por exemplo, um senhor Bakairi indagou: "Isso é peixe? A gente náo come isso, come peixe do rio, come pintado". Ou então, no comentário de um Marubo: "A gente não sabe bem o que está comendo, a comida sai daquele buraco e a gente também não conhece quem faz" [em referência à pequena abertura quadrada entre a cozinha e o refeitório, por onde os pratos de comida são entregues].7 A limpeza e arrumação também estão a cargo de funcionários e os deslocamentos são motorizados, intensificando a passividade dos hóspedes. Frequentemente, pacientes e acompanhantes comentam que suas roupas estão ficando pequenas porque o corpo está cada vez mais pesado e com preguiça. Já a alma pode ficar mais solta, querendo ir embora, como falou uma moça Guarani.

Essa moça, que acompanhava seu filho em tratamento, também comentou que já sentira as paredes da Casai tremendo pela presença de espíritos. Estes se manifestam para muitos pacientes em experiências oníricas ou em situações cotidianas na Casai. Um rapaz Wapishana, por exemplo, contou que espíritos lhe falavam toda vez que ia ao banheiro do andar térreo da casa, fazendo-o defecar sangue. Ele era acompanhante, mas depois desse relato à equipe de enfermagem foi encaminhado como paciente aos setores de psiquiatria e proctologia do Hospital São Paulo. A intervenção biomédica buscou silenciar os espíritos, dando-lhes a forma de doença mental a ser tratada com medicaçáo de tarja preta. O rapaz contou-me que os remédios tinham afastado um pouco os espíritos, mas ele acabara ficando também emudecido, sem vontade de se comunicar com as pessoas à sua volta.

Os remédios circulam na Casai transportados pelos técnicos em copinhos de plástico com o nome do paciente escrito com caneta hidrográfica. Eles fazem parte dos cuidados que posicionam as pessoas como pacientes, assim como os instrumentos que trazem à existência a pressão arterial, os batimentos cardíacos, a temperatura, o índice glicêmico, o chiado nos pulmôes, entre outros manejados cotidianamente pelos técnicos de enfermagem e que fazem visível o corpo, sob o olhar clínico, como um sistema biológico.

Em sua pesquisa na Casai-DF, Cruz e Guimarães (2016) a reconhecem como instituição total (no sentido de Goffman, 1974), mas enfatizam as microrresistências indígenas aos micropoderes (no sentido de Foucault, 1999) que incidem sobre corpos e pessoas. A maioria dos indígenas que pude conhecer na Casai-SP não se adequa ao modelo foucaultiano de internalização e submissão à normatividade biomédica, mas experimenta intervençóes em seus corpos (por medicamentos, alimentos, procedimentos clínicos etc.), incluindo a regulação dos tempos (pelos horários 
dos medicamentos, refeiçóes, consultas, exames e cirurgias, da burocracia que autoriza as passagens de ida e de volta etc.) e dos espaços (por normas de comportamento, higiene e de deslocamento, entre outras).

Os modos pelos quais pacientes se deixam ou não - apreender pelos cuidados da equipe de enfermagem são imensamente variáveis. A posição de paciente indigena passa por deixar-se apreender por tais cuidados, modulando-os, ou por evitá-los. Por sua vez, o cuidado por parte dos profissionais de enfermagem pode implicar "invadir um pouquinho", como formulou uma técnica (Macedo, 2018) ${ }^{8}$ :

Eu já trabalhei em hospital normal e percebo que os indígenas sáo bem mais quietos, não se queixam. Entáo você tem que ter uma percepçáo bem maior e tem que invadir um pouquinho pra eles falarem alguma coisa. Já aconteceu várias vezes de eu perceber que eles estáo com dor, perguntar o que está acontecendo, mas não falarem, aí você vai ver e o paciente está com a pressão super alta.

Outra técnica certa vez comentou: "As mães Guarani, se elas não sentirem confiança, você não consegue encostar nelas" (Macedo, 2017a). Essa confiança pode levar tempo e, além dos cuidados na Casai, também costuma ganhar corpo nas horas compartilhadas nas salas de espera dos ambulatórios e hospitais. Um técnico sempre acompanha o paciente, além do acompanhante indígena, e, nas vezes em que estive presente, podíamos ficar horas em silêncio, por vezes entretidos com os respectivos celulares, mas em muitas situações acabávamos conversando sobre a vida ou sobre nossas vidas, quando o que estava em jogo não eram cuidados que fazem visível um corpo biológico.

Para além das horas nas salas de espera dos hospitais, brincadeiras e conversas entre técnicos e pacientes também ocorrem na Casai, em momentos ociosos ou durante os procedimentos de enfermagem. A relevância dos engajamentos subjetivos foi assim exemplificada por uma técnica: "ela está sempre com dor de cabeça. Um dia me contou que soube que o filho está triste na aldeia, com saudade dela, sem comer. Então não dá pra gente só levar medicamento e ficar com a pasta na mão" (Macedo, 2018a). Essa dimensão afetiva do acolhimento é a que mais se aproxima da convivialidade do parentesco e, por isso, da humanização desses profissionais para muitos pacientes e acompanhantes. Por sua vez, entre os profissionais, muitas informaçōes sobre pacientes são obtidas nessas conversas e depois compartilhadas nas reunióes semanais da equipe de enfermagem, aproximando-se do ideal do cuidado humanizado, que considera as dimensōes subjetivas e socioculturais do paciente no tratamento.

Essa familiarização, contudo, nem sempre se efetiva e, para alguns indígenas, há técnicos que são excessivamente invasivos nas perguntas, brincadeiras e aproximaçóes físicas (dando beijos e abraços de modo constrangedor); outros podem parecer excessivamente evasivos, negligentes ou arrogantes em suas explicaçóes, determinaçóes e repreensóes. O mesmo se passa entre os técnicos, para quem alguns pacientes e acompanhantes são ignorantes, grosseiros, folgados ou mal-agradecidos, enquanto estabelecem intensos vínculos afetivos com outros.

Entre muitos povos indígenas, a familiarizaçáo implicada no cuidado pode ser um modo de amenizar a potência predatória da alteridade (Viveiros de Castro, 2007; Fausto, 2008). Particularmente, elicitar o cuidado dos não-indígenas pode ser um modo de evitar sua predação (Bonilla, 2005). Nessa direção, em uma reunião em que acusava funcionários de negligência no atendimento, um Ikpeng argumentou: "Aqui na Casai sou filho da Denise, da Carla, da Janaina... somos filhos dos funcionários". Posicionarse como "filho" naquele contexto pode ser pensado como uma alternativa a ser "presa" do outro, mas a reversibilidade dessas posiçôes está sempre em jogo. Daí o desafio sempre posto de manejar tais relaçóes, tanto por parte dos pacientes e acompanhantes como dos funcionários.

Em sua etnografia junto a profissionais de saúde que trabalham em aldeias Munduruku, Dias da Silva $(2010$, p. 5) aponta que aqueles reconhecem o "saber se relacionar com os indios" como fundamental para persuadi-los a seguirem os procedimentos necessários para prevenção ou tratamento de doenças. Esse conhecimento não raro é associado por esses profissionais à relevância de seu papel mediador $\mathrm{e}$ tutelar nos hospitais, onde os profissionais desconhecem as especificidades culturais dos indígenas. ${ }^{10}$ 
Diferentemente dos profissionais que atuam em campo, a equipe da Casai-SP, em sua maioria, nunca trabalhou em aldeias. Mesmo assim, além de subjetividades, o cuidado humanizado ali também costuma fazer visível culturas. É comum ouvir técnicos associarem certas características de temperamento ou comportamento a povos específicos e, ao comentarem sobre o trabalho junto aos indígenas, destacarem o aprendizado a respeito de diferenças culturais. Por exemplo, uma técnica que estava em seu quarto mês de trabalho assim comentou: " $E$ u achava que era tudo parecido. Eagora estou percebendo como cada etnia é diferente. Isso é importante pra trabalhar melhor com eles" (Macedo, 2016).

Guimarães e Rosa (2019) comentam que características desqualificadoras por vezes são vinculadas a certos povos indígenas por funcionários da Casai-DF, como falta de higiene, tendência ao furto ou comportamento grosseiro. Ouvi comentários semelhantes de alguns funcionários na Casai-SP, os quais pareciam menos engajados no aprendizado com o outro do que em ensiná-lo e, em alguns casos, convertê-lo. Não são poucos os indígenas que recebem convites para refeiçôes, cultos e doaçôes de roupas e brinquedos em igrejas durante a estadia na Casai, às quais por vezes são apresentados por funcionários.

Entre os pacientes, porém, a posição de alguém a ser familiarizado pelos cuidados biomédicos ou outros (como o acolhimento em igrejas) está longe de ser passiva ou fixa. Há casos, inclusive, em que funcionários é que demandam cuidados. Um pajé do Alto Xingu que estava na Casai como paciente contou-me que uma técnica lhe pediu ajuda para trazer de volta o marido que a havia abandonado. Ele ainda contou de uma pajelança que fez na casa de outra técnica, buscando curar o câncer da máe dela. Também ouvi de um técnico que, certa vez, ele encontrou duas colegas com dois indígenas e que elas pareciam inconscientes, alegando em seguida terem sido enfeitiçadas pelos pacientes.

Apreender coisas e subjetividades dos nãoindígenas, portanto, não implica apenas a posição de paciente na Casai. Para muitos, tais apreensóes podem ampliar capacidades relacionais na cidade e nas aldeias. Entre aqueles que não estão muito debilitados pela doença, pode haver um empenho de familiarização com a cidade de São Paulo, o que costuma ocorrer por intermédio de outros pacientes ou acompanhantes que já estão há mais tempo na Casai. Boa parte dos pacientes recebe recursos do TFD (Tratamento Fora de Domicílio, programa do SUS que fornece diárias) em sua estadia em São Paulo, e em diversas ocasiōes acompanhei incursōes coletivas em locais como Brás, Rua 25 de Março, entre outras na regiáo central para comprar roupas, calçados, eletrônicos, miçangas e outros produtos. Tais itens são usados por ocasiấo das consultas, exames, passeios e em outros espaços em que buscam apreender a perspectiva dos não-indígenas da cidade. Por sua vez, tais produtos da cidade também são modos de elicitar olhares e mobilizar relaçóes de cuidado nas aldeias, seja presenteando parentes ou afins, seja pela potência diferencial de seu uso ou posse.

Além da aquisição de coisas e das relaçôes que engendram, percorrer uma cidade como Sáo Paulo costuma ser motivo de apreensões no duplo sentido da palavra: o receio por seus perigos e formas de captura (não são raros os indígenas que foram assaltados, se perderam, foram assediados ou insultados por comerciantes, enganados na compra de produtos etc.) e o extremo interesse pela aquisição de conhecimentos e capacidades diante da pletora de construçôes, pessoas, coisas, ritmos, atividades. Avançar nessas experiências desviaria o foco do espaço relacional das instituiçôes de saúde, mas é importante pontuar como São Paulo participa dessas relaçóes, seja maximizando o sentimento de vulnerabilidade e confinamento que se experimenta na Casai, seja ampliando possibilidades agentivas de modo a não se fixar na posição de paciente indígena.

Há ainda que se mencionar a centralidade dos outros hóspedes no acolhimento dos que chegam à Casai, sobretudo entre aqueles que ficam longos períodos ou que voltam periodicamente. Como em outros contextos interétnicos, é comum que desconhecidos se tratem mutuamente com a expressão 'parente'. Mas é apenas com a convivência, trocas de favores e cuidados que a relacionalidade do parentesco se efetiva. Além das incursôes conjuntas na cidade para compra de produtos industrializados, são frequentes os intercâmbios de enfeites e artefatos confeccionados pelos pacientes, bem como de técnicas, estilos e materiais. Práticas 
sexuais também ocorrem intensamente (algo também destacado por Rosalen, 2008 sobre a Casai-Macapá), tanto consentidas como impostas, podendo amenizar ou intensificar sentimentos de vulnerabilidade. Mesmo as relaçóes entre pacientes e seus acompanhantes podem transformar-se durante a estadia, ensejando uma aproximação mais intensa ou diferente do que ocorria na aldeia. A Casai e São Paulo são assim lugares de contaminaçôes, vulnerabilidade e feitiços, mas também de novos aparentamentos, aquisição de vínculos e de capacidades - como o são as doenças.

\section{Coordenaçáo}

Geralmente, alguns dias após a chegada do paciente à Casai, um segundo acolhimento é feito no Ambulatório do Índio, cuja equipe é associada a um projeto de extensão universitária vinculado ao Departamento de Medicina Preventiva da Unifesp e de ampla atuaçáo no campo da saúde indígena desde 1965, o Projeto Xingu. ${ }^{11}$ Criado em 1992, o Ambulatório do Índio ocupa um pequeno sobrado a poucos metros do hospital. Segundo informaçáo da coordenadora do Ambulatório em 2015, cerca de $30 \%$ dos atendimentos eram de pacientes da Casai e o restante correspondia a indígenas que chegavam por livre demanda.

No website do Projeto Xingu, o Ambulatório do Índio é apresentado como responsável pelo acolhimento de pacientes indígenas e pela coordenação do cuidado, mediando itinerários diagnósticos e terapêuticos nas diferentes especialidades e setores do Hospital Sáo Paulo. ${ }^{12}$ Para além do Ambulatório, a coordenação do cuidado no campo da saúde humanizada costuma estar vinculada à centralidade da enfermagem e da atençáo básica na mediação do fluxo nas especialidades e nos três níveis do atendimento (primário, secundário e terciário), sendo, portanto, parte do acolhimento (Starfield, 2004).

Além do acolhimento na Casai e da familiarização do paciente com a instituição, há, portanto, a familiarizaçáo do paciente com diagnósticos e tratamentos associados à performaçáo de um corpo biológico. Em seu acolhimento aos indígenas, a equipe no Ambulatório busca traduzir e conferir coerência a exames clínicos, laboratoriais e de imagem, bem como a procedimentos que podem acontecer em diferentes especialidades do hospital. Mas não apenas corpos biológicos vêm à cena. A página virtual do Ambulatório destaca uma "abordagem que valoriza os aspectos culturais envolvidos na determinação das doenças, visando minimizar os conflitos entre o saber biomédico e o tradicional indígena" ${ }^{13}$ Enfermeiros e médicos buscam, sempre que o paciente se dispóe a contar, conhecer e considerar os nexos causais da doença e as terapêuticas mobilizadas por práticas de conhecimento nas aldeias. Ainda, a equipe busca fazer as mediaçóes necessárias para que algumas dessas terapêuticas tenham espaço dentro do hospital, viabilizando a atuaçáo de rezadores e pajés.

Ao longo de 2015, acompanhei reunióes semanais no Ambulatório entre parte de sua equipe e da Casai, em que casos clínicos eram abordados num esforço conjunto de coordenação do cuidado. Entre os temas debatidos figuravam articulaçóes para lidar com dificuldades de agendamento de consultas, exames e intervençóes que, por vezes, retardam em semanas ou meses o retorno dos pacientes. As equipes também buscavam monitorar o estado psicológico e clínico dos pacientes e eventualmente mediar conflitos entre pacientes e médicos especialistas. Por exemplo, um médico pediu a um homem Tupinambá a carteira da Funai, duvidando que ele fosse indígena, e este ameaçou procurar o MPF para denunciar o profissional.

Para além das tecnologias leves, a coordenação do cuidado remete ainda à coordenaçáo da multiplicidade ontológica das doenças, a exemplo dos diferentes materiais que vêm à existência em exames clínicos em diversas especialidades, nos exames laboratoriais ou de imagem, na experiência dos pacientes etc. Retomando Mol (2002), é preciso coordenação para que essas múltiplas existências sejam reconhecidas como uma única doença. Tomo como exemplo o adoecimento de uma menina de 12 anos que veio do Alto Xingu acompanhada do pai. ${ }^{14}$ Como foi tematizado na reuniấo, o pai já havia perdido um filho diagnosticado com leucemia e agora a filha vinha apresentando os mesmos sintomas: tonturas, palidez, sangramentos.

Após o acolhimento no Ambulatório, a menina fez exames iniciais e, quando o hemograma apresentou baixo índice de células sanguíneas, ela foi encaminhada 
ao hematologista. A especialista solicitou um Teste de Fragilidade Cromossômica e ela foi diagnosticada com Anemia de Fanconi, doença genética que estabelece propensão a alguns tipos de câncer, entre outros problemas, cujo tratamento implica transplante de medula. Para controlar os sangramentos, a hematologista prescreveu um medicamento geralmente indicado para casos de puberdade precoce e endometriose grave.

Hemogramas posteriores, contudo, não apresentaram melhora nas plaquetas da menina. A enfermeira da Casai informou que ela também vinha apresentando quadro febril e algumas verrugas apareceram em sua pele. Foi então agendada uma consulta com um dermatologista, na qual foi requerida biopsia para verificar malignidade nas lesóes. Coube ao Ambulatório coordenar a patologia que tomou forma no hematologista - alteraçóes nas plaquetas - e a que tomou forma no dermatologista- lesóes que demandam biópsia -, estabelecendo a impossibilidade de fazer qualquer corte nos tecidos do corpo da menina sob perigo de hemorragia.

Também como parte da coordenação do cuidado, cabia à equipe encontrar um doador de medula para a menina, já que exames laboratoriais estabeleceram a incompatibilidade dos pais. $\mathrm{Na}$ reunião então se decidiu que amostras de sangue seriam colhidas durante a vacinação que seria feita em comunidades no Alto Xingu. Encontraram assim um primo de $1^{\circ}$ grau com 15 anos. O pediatra do Ambulatório também anunciou que estava em contato com uma médica de um hospital em Curitiba para viabilizar o transplante, de modo que o longo tratamento posterior poderia ser feito na Casai dessa cidade.

Ainda, a coordenação do cuidado implicava lidar com a ansiedade do pai e da menina pelo período prolongado na Casai. O pai alegava que ela chorava muito querendo ir para casa, e que se fosse caso de feitiço o transplante poderia ser ineficaz. Mas a equipe conseguiu convencê-los a permanecer em São Paulo e depois ir a Curitiba. Segundo algumas trocas de mensagens posteriores que fiz com esse pai por rede social, a menina se recuperou bem do transplante e voltaram para a aldeia, mas foi muito sofrido viver tantos meses nas Casais de São Paulo e de Curitiba.

Para além desse caso, hóspedes na Casai se ressentem da dificuldade de seguir cuidando e serem cuidados pelos parentes que ficaram na comunidade. A depender do caso, fica-se longe de filhos, do cônjuge, do pajé, da roça, de rituais e de outras relaçóes que constituem a pessoa. A suspeita de feitiçaria que envolve muitos adoecimentos pode fazer com que o sujeito se perceba ainda mais vulnerável em razão do enfraquecimento dos vínculos com os parentes e o acirramento de possíveis agressões. Há também casos em que o afastamento em São Paulo pode ser providencial para amenizá-las; ou, ainda, que novas agressóes sejam ensejadas na Casai ou nos hospitais.

A equipe do Ambulatório do Índio bem sabe que, para a maioria de seus pacientes, o discurso biomédico está longe de ser uma verdade externa a agenciamentos mais amplos e heterogêneos que escapam ao controle e ao conhecimento dos médicos. Via de regra, todos na equipe já viveram períodos na Terra Indígena Xingu ou em outras comunidades (Pereira, 2012; Assumpção, 2014). Assim, nas reuniōes com a Casai buscam coordenar a multiplicidade ontológica das doenças fazendo visíveis corpos biológicos, mas também buscam fazer visíveis culturas e relaçóes que não estão circunscritas ao que os dispositivos biomédicos performam.

Os papeis mediadores das equipes da Casai e do Ambulatório não são, contudo, equivalentes. O Ambulatório protagoniza a orquestração do itinerário terapêutico do paciente, enquanto a Casai deve seguir as orientaçóes do Ambulatório e dos especialistas. Os médicos e enfermeiras do Ambulatório atendem os pacientes, conversam com os especialistas e acompanham internaçóes; já os técnicos da Casai acompanham os pacientes em todas as consultas, exames e intervençôes, além do convívio e cuidados na casa. A equipe da Casai também faz reunióes semanais internas para discussão dos casos e, em algumas que acompanhei, técnicos alegaram ter uma visáo mais abrangente do paciente e do tratamento, mas que são pouco ouvidos pelos médicos. Por outro lado, no Ambulatório, por vezes, a equipe reclama da falta de visão de técnicos para as especificidades do cuidado entre povos indígenas.

Mesmo entre os médicos e enfermeiros do Ambulatório, porém, não raro é difícil fazer visíveis tais especificidades, sobretudo quando não se trata de povos xinguanos. Particularmente, a interlocução 
em português pode produzir opacidade, a depender da fluência do paciente ou acompanhante, e do que essa língua pode ou não fazer visível nos enredos e agentes envolvidos no adoecimento. Nessa direção, um rapaz Guarani, certa vez, perguntou se eu poderia ajudá-lo a explicar ao doutor o que é o nheeẽ (cuja tradução por 'alma' vinha sendo insuficiente) ${ }^{15}$, para que ele entendesse que de nada adiantaria o trabalho dos médicos se o nheẽe de seu filho de cerca de dois anos se afastasse ou partisse de vez. Por isso, ele insistia que seu filho também estivesse sob o cuidado de um opitaivive ('aquele que fuma', comumente traduzido pelos Guarani como líder espiritual ou pajé), trazendo conforto ao nheẽe e combatendo agentes agressores no corpo, no ambiente do hospital e na Casai. Mas minha participação não foi necessária, pois o médico alegou que seu respeito pelo tratamento espiritual independe de sua compreensão sobre ele.

Os líderes espirituais Guarani comumente se valem do cachimbo com tabaco como um dos instrumentos fundamentais para ver e agir sobre o objeto patogênico no corpo, além das mãos que percorrem as regióes afetadas, de cantos, do mbaraka mirĩ (chocalho), entre outros elementos a que podem recorrer. O sopro da fumaça do cachimbo expulsa o agente agressor e reveste o corpo com uma malha de proteçấo ao nheee (Macedo, 2013, 2017).

Como o diagnóstico biomédico do menino apontava dispneia em razão do não desenvolvimento de um dos pulmóes, o desafio na coordenaçáo do cuidado no Ambulatório implicava lidar com a divergência entre a fumaça como agente patogênico e como agente terapêutico. A despeito do pai do menino ter cogitado que uma tradução acurada pudesse fazer visível aos médicos a existência do nheẽe, o que estava em jogo não era um acordo epistemológico, mas um desafio cosmopolitico (Stengers, 2007), em que uma ação conjunta se faz possível sem que haja um consenso, sem que um significado se imponha, ou que se estabeleça um denominador comum entre aqueles envolvidos. Com apoio logístico do Ambulatório e da Casai, várias sessōes de cura com diferentes líderes espirituais ocorreram no hospital, na Casai e em duas aldeias em São Paulo. Em ao menos uma delas, o pajé fez o tratamento sem usar o cachimbo com tabaco, em outra usou a fumaça de modo comedido e em outras usou sem restriçóes.

O pai também insistia na necessidade de o menino passar mais tempo na aldeia, pois as estadias prolongadas no hospital ou na Casai tendiam a afastar o nheẽe, cujo assentamento no corpo dependia do convívio com pessoas, comidas, cheiros e tudo mais da vida entre os parentes. O pai inclusive me dizia que, na aldeia, a respiração do filho não era ofegante como em São Paulo. As equipes do Ambulatório do Índio e da Casai recorreram então à equipe de saúde no polo-base na aldeia em que ele vivia para verificar a possibilidade de uso do cilindro de oxigênio e de resgate de emergência, caso fosse necessário. Mas o polo-base disse que náo tinha condiçóes de assumir essa responsabilidade. Então pessoas do Ambulatório e da Casai, as quais acompanhei junto com o pai do menino, foram até a aldeia no Vale do Ribeira (cerca de três horas de viagem de Sáo Paulo) para conhecer o lugar, conversar pessoalmente com a enfermeira do polo-base e com os parentes na comunidade. Conseguiram estabelecer um acordo em que o menino passaria períodos curtos na aldeia, alternando com a estadia na Casai.

Após meses em tentativas frustradas de tratamento, os médicos chegaram à conclusão de que seria necessário extrair o pulmáo atrofiado da criança. Os pais recorreram aos líderes espirituais e aos parentes na aldeia para que uma decisão conjunta fosse tomada, e autorizaram a cirurgia. $\mathrm{O}$ pai disse que os médicos não viam o que os líderes espirituais podiam ver, nem sabiam o que causava a dificuldade de respirar, ou, em sua expressão, o cansaço, do menino. Ele aventava que desentendimentos com a esposa durante a gestação poderiam ser uma das causas do desconforto do nheẽe, deixando o corpo mais vulnerável. Segundo o rapaz, mesmo sem poder ver e considerar essas causas, os médicos e seus aparelhos viam que o pulmáo estava pequeno e que extrai-lo poderia tirar a doença também. A cirurgia foi feita e, depois de alguns meses alternando períodos entre a aldeia e a Casai, a criança teve alta e seu pai sempre posta em uma rede social fotografias em que ela aparece brincando na aldeia.

Ao longo do processo, os pais e seus parentes pareciam menos preocupados em entender ou aceitar 
as explicações dos médicos, ou de ver o que eles viam nos exames, e mais em que os médicos estivessem vendo a doença em uma forma - que não é a única nem a verdadeira - na qual pudessem combatê-la. Muitos trabalhos sobre processos de adoecimento entre povos indígenas apontam composiçōes entre práticas de conhecimento biomédicas e xamânicas que prescindem de convergência nosológica ou etiológica (Gallois, 1991; Barcelos Neto, 2006; Buchillet, 2002, 2004; Langdon, 1991; Langdon e Garnelo, 2004; Garnelo, 2003; Dias da Silva, 2010; Araújo, 2015; Rosalen, 2017).

Em meio à diversidade dessas composiçóes, o controle das alteraçóes no corpo decorrentes dos cuidados médicos pode ser crivado de ambivalências e desafios para os indígenas, como a circulação indevida de substâncias como sangue, fezes e urina, ou quanto aos alimentos adequados e perigos de contaminação. Muitas situações podem gerar insegurança e consternação, como transfusões, transplante de órgãos, proibição ou imposição de jejuns, medicação desconhecida, entre outras. Entretanto, para muitos que estão no hospital ou na Casai, a instabilidade ontológica característica do adoecimento pode favorecer uma maior abertura a essas experimentaçôes. Como apontou Street (2014, p.142) em relação aos diagnósticos no hospital em Madang, a incerteza não se apresenta como um problema epistemológico, mas sobretudo relacional.

Como o espaço tende a estabilizar a perspectiva de seus donos e habitantes (Nunes, 2013), quando se está em um hospital há agentes agressivos que podem ser apreendidos pela perspectiva dos médicos e combatidos por seus remédios e intervençóes. Em vez de uma realidade exterior a processos de subjetivação, para muitos indígenas o adoecimento pode remeter a um objeto relacional a ser capturado numa forma específica pelo olhar clínico dos médicos e seus equipamentos. Tal captura tampouco diz respeito a uma representação de algo dado - ou seja, a biomedicina como sistema simbólico -, mas a uma apreensão com efeitos transformacionais, daí sua eficácia.

O corpo como "mais do que um e menos do que muitos" (Mol, 2002) pode alcançar ainda maior complexidade quando, para além dos instrumentos biomédicos de visão, muitos indígenas reconhecem os próprios corpos dos médicos ou enfermeiros como dispositivos afectivos - que resultam do que comem, do espaço em que vivem, da proveniência de suas almas, do que fazem e do que ou por quem foram feitos - capazes de ver (ou fazer visível) algumas coisas e não ver outras. Assim, não se trata apenas de fazer visível, mas visível para quem e em quais condiçóes.

Pacientes indígenas costumam reconhecer órgãos e tecidos internos com os quais lidam os médicos, mas isso não significa que os apreendam como entes biológicos. Rosalen (2017, p. 29-30), por exemplo, remete a conversas com alguns Wajāpi, em que um deles comenta que guerras e práticas antropofágicas num tempo antigo fizeram com que conhecessem o corpo por dentro, enquanto outros destacam o conhecimento sobre os órgãos advindo de práticas de caça e preparo dos animais para consumo. A autora (Rosalen, 2017) e Gallois (1988) ressalvam, entretanto, que, de acordo com os Wajăpi, os órgãos e partes que constituem o corpo são providos de princípios vitais, â, que lhes conferem subjetividade e capacidade metamórfica. Gallois (1988, p.176) também aponta a inexistência de uma palavra na língua Wajāpi que designe corpo em sua totalidade, de modo que não há matriz única e unificadora de subjetividade, indo de encontro a premissas do corpo como sistema biológico.

Para muitos pacientes indígenas, o importante é que os brancos possam apreender o agente agressivo como doença, dando-lhe uma forma na qual possam lidar com ela. Já para muitos profissionais de saúde, no atendimento humanizado importa que os indígenas possam fazer visíveis aspectos subjetivos e culturais em uma forma que lhes permita lidar com eles como pacientes. Uma fala de um técnico de enfermagem da Casai explicita essa orientação (Macedo, 2016a):

Essa questão das duas culturas, essa troca de informação é muito importante. Eu acredito na minha ciência, ótimo, mas você tem que pelo menos respeitar a ciência do próximo. Você pode dizer "ah, não acredito em pajelança, não acredito nisso, não acredito nos xamãs”. Você pode não acreditar, mas você não pode desrespeitar. Você tem que entender o espaço dele, e muitos casos que passaram por aqui só tiveram efeito positivo quando soubemos tratar dos dois saberes juntos, 
da medicina nossa com a medicina do indígena. $\mathrm{O}$ paciente se sente melhor, consegue desenvolver melhor o tratamento e nosso trabalho acaba desenrolando muito melhor.

Este e outros profissionais na área de saúde indígena defendem uma postura de relativismo cultural ('você pode não acreditar, mas tem que respeitar') e reconhecem a eficácia do trabalho conjunto de diferentes ciências, medicinas, saberes ('o paciente se sente melhor e nosso trabalho se desenrola melhor'). Para muitos desses profissionais, a coordenação do cuidado demanda a articulação de diferentes pontos de vista e intervençóes sobre uma doença dada. Mas a coordenação do cuidado também é um trabalho daqueles que são cuidados, particularmente no caso de indígenas que não compartilham o pressuposto de uma doença dada, e sim a existência metamórfica de corpos visíveis e invisíveis, cujas formas não precedem as intervençôes, demandando o manejo de relações na Casai, nos hospitais e em suas comunidades.

\section{Atençáo}

Quando era representante da Terra Indígena Guarani do Rio Silveira no Conselho Distrital de Saúde Indígena do Dsei Litoral-Sul, Karai Tataendy, certa vez, disse-me que as doenças nunca são 'normais', no sentido de serem processos biológicos desprovidos de intencionalidades subjetivas (de seres humanos e extra-humanos). Mesmo uma gripe, uma diarreia ou qualquer doença que os médicos vejam como problemas biológicos envolvem "aqueles que não vemos" ( jaexa ẽ̃ vảe), ou seja, alguma agência espiritual. Mas há doenças que o olhar dos médicos não consegue capturar ou combater, as quais os Guarani chamam de nhe ê mba'eaxy, que traduzem como "doença espiritual" e que só podem ser reconhecidas pelo oexa mara'ey (olhar sem limitaçóes) dos líderes espirituais (Macedo, 2013, 2017). Para Karai Tataendy e outros Guarani, o que difere essas doenças de outras é a eficácia ou náo da medicina dos brancos, e não que umas sejam causadas por espíritos e outras sejam meramente físicas. Até porque a divisão entre corpo e espírito é também relacional e reversível.
De acordo com o que pude acompanhar na Casai, desistências no tratamento biomédico ocorrem principalmente quando há dificuldades de diagnóstico, quando o prognóstico não prevê cura ou quando o tratamento não apresenta resultados. Assim como o hospital melanésio para o qual se volta Street (2014), a indisponibilidade ou precariedade de equipamentos e serviços pode tornar mais desafiante a produção de corpos biológicos cujas doenças possam ser diagnosticadas e tratadas pela biomedicina. Mesmo quando disponíveis, porém, muitos pacientes indígenas apontam a incapacidade de quaisquer dispositivos biomédicos de reconhecer algumas doenças numa forma em que possam manejá-las. Na expressão de um Wauja a Barcelos Neto (2006, p. 9), essas seriam "doenças de indio"e só os pajés podem enfrentá-las.

Certa vez, uma mulher Trumai contava-me sobre os desafios de ser agente indígena de saúde na TI do Xingu e eu comentei que a medicina dos brancos era muito complicada de lidar. Mas ela discordou: "Não, não. A medicina dos brancos até que ésimples, complicada é a dos indios, por isso os médicos não conseguem arrumar o que os feiticeiros estragam" (Macedo, 2015). Nesses casos, a biomedicina costuma ser reconhecida por pacientes indígenas como um cuidado paliativo, não porque inexista cura, mas porque a ciência dos brancos é incapaz de promovêla. Ela pode combater sintomas, mas por vezes náo reconhece o agente agressor de modo a conferir-lhe uma forma que permita uma intervençáo efetiva.

Por sua vez, há povos que reconhecem doenças em que o tratamento xamânico é ineficaz, devendo ser tratadas pelos médicos e não raro chamadas de "doenças de branco". Em geral, elas são associadas a males decorrentes do contato com os não-indígenas, como sarampo, gripe, catapora, malária, entre outras. Como comentam Garnelo (2003, p.57), referindo-se aos Baniwa, e Buchillet (2002, p.121), aos Desana, na região do Rio Negro elas são chamadas de "doença passageira", tanto por seu potencial de contágio como por sua efemeridade. Já Gallois (1991, p.198), a partir de sua interlocução com os Wajápi, aponta para o pragmatismo da categoria "doença de branco" como um modo de mobilizar o cuidado dos brancos e controlar sua intervençấo, ou seja, de elicitar seus cuidados de forma a posicionar-se ativamente nessa 
relação. A questão são os efeitos, e não as causas, de modo que a medicina dos brancos pode ser eficaz contra agentes agressivos sem que estes precisem se enquadrar nos modelos etiológicos biomédicos. A incapacidade dos xamãs em tratá-las é também de ordem xamânica e tais doenças ganham sentido a partir das conceituaçóes indígenas.

Para muitos povos, os brancos não são apenas transmissores de doenças que estão em seus corpos, mas suas coisas, comidas e até remédios podem aumentar a vulnerabilidade a agenciamentos agressivos. $\mathrm{Na}$ etiologia Yanomami, por exemplo, coisas dos brancos - do pó que se levanta dos tecidos com que os brancos os presentearam nos primeiros contatos até a chaminé das indústrias - emanam a fumaça xawara, com forte efeito patogênico (Kopenawa e Albert, 2015). Os efeitos de sua alimentação também são apontados por muitos povos, como alguns de meus interlocutores Guarani, que atribuem à comida dos brancos uma maior sujeira (-ky'a) no corpo, aumentando seu peso, perecibilidade e vulnerabilidade (Macedo, 2019).

Particularmente na Casai, a recepção de comida e remédios, a inatividade, a coabitaçáo com desconhecidos e açóes da equipe de saúde podem produzir a dupla percepção de cuidado e vulnerabilidade. Não raro, sintomas inexistentes antes da chegada em São Paulo se fazem presentes durante a estadia na Casai. Ou então exames e diagnósticos biomédicos trazem novas doenças à existência, de modo que quase todos os acompanhantes se tornam pacientes. Assim, se a doença chega antes do paciente na Casai, o oposto ocorre no caso dos acompanhantes.

Uma das frentes de atuação do Ambulatório do Índio é a atenção primária aos indígenas que chegam na condição de acompanhantes dos pacientes. Visando suprir a precariedade dos serviços em muitos polos-base nas comunidades, o Ambulatório agenda exames e consultas médicas e dentárias com pacientes e acompanhantes. Como comentou uma enfermeira (Macedo, 2015a):

O paciente vem com uma doença de média ou alta complexidade, mas ele e o acompanhante podem vir também com problemas de atenção básica, como parasitose do filho, subnutrição, saúde da mulher, saúde da criança, micose, oftalmo, odonto etc., e o Ambulatório tem um papel importante nisso.

Assim, a atenção se expressa também no reposicionamento dos acompanhantes como pacientes. Um Xavante que acompanhava sua esposa comentou comigo que pegou diabetes na Casai, pois não tinha nem sentia nada antes de fazer exames e ser diagnosticado com a doença. ${ }^{16} \mathrm{Tal}$ afirmação vai ao encontro do que aponta Mol (2002) sobre como as doenças não precedem os dispositivos biomédicos que lhes trazem à existência. A despeito de emergirem doenças em práticas de diagnóstico e tratamento nessas instituiçóes, vimos que há também o empenho de incluir diagnósticos locais, terapêuticas tradicionais e cuidadores das comunidades na coordenação do cuidado. Esse é um horizonte normativo da saúde indígena (Cardoso, 2014; Langdon e Garnelo, 2017) e, de modo mais amplo, da atenção diferenciada, em que práticas biomédicas devem ser conciliadas com o respeito a singularidades subjetivas e socioculturais do usuário (Starfield, 2004).

Como destacam Langdon e Garnelo (2017), a legislação determina o respeito e a priorização de terapêuticas tradicionais sobretudo na atenção primária, mas essa disposição normativa encontra pouca efetividade na atuação de boa parte das equipes multiprofissionais nas comunidades indígenas. No mesmo sentido, Cardoso (2014) destaca a inoperância da atenção diferenciada quando os indígenas precisam se valer de hospitais do SUS, onde o respeito a costumes e especificidades terapêuticas não raro é negligenciado ou considerado um "privilégio" indevido num sistema que pressupóe acesso universal e equitativo entre seus usuários.

Atuando como mediadoras entre os pólos-base e os hospitais, as equipes do Ambulatório do Índio e da Casai-SP vivem cotidianamente esses desafios. Em relação aos pólos-base, funcionários da Casai comentam com frequência dificuldades na obtenção de documentos, ou em garantir a continuidade do acompanhamento nas aldeias, ou de viabilizar a participação mais efetiva de parentes e especialistas tradicionais, entre outras. A seu turno, nos hospitais não raro encontram resistência em antecipar 
agendamentos, adaptar o cardápio nas internaçóes e outras práticas que impliquem o reconhecimento de necessidades específicas no atendimento aos indígenas. O Ambulatório do Índio tem um papel importante nessas articulaçóes, como viabilizar pajelanças ou consultas e intervençōes não previstas na chegada do paciente.

Vivenciando limites e possibilidades da atenção diferenciada, vários profissionais na Casai e no Ambulatório apontam que ela incorreu na sua própria transformação. Em pesquisas junto a profissionais do Ambulatório, Pereira (2012) e Assumpção (2014) remetem a várias histórias de autorreflexividade $\mathrm{e}$ deslocamentos conceituais a partir de experiências de alteridade com os indígenas nas aldeias e na cidade, reiterando o cuidado como espaço heterotópico ( $\mathrm{Mol}$, 2008). Já entre os médicos especialistas nos hospitais, as abordagens variam muito. Acompanhei pacientes por horas em salas de espera repletas de pessoas, seguidas de consultas extremamente rápidas, em que o médico mal olhava para o paciente, observando apenas resultados de exames e o prontuário para prescrever procedimentos e ou remédios. Náo havia ali interesse em ver nada além das doenças que os dispositivos biomédicos performavam, ou esse interesse fora considerado supérfluo diante do montante de pessoas aguardando para serem atendidas.

Há também casos em que o próprio paciente e/ou acompanhante evita falar, por dificuldades com a língua ou pela pouca disposição em estabelecer conexóes com os médicos, de modo que o técnico da Casai assume o papel de mediador. Nas consultas, a participação dos técnicos costuma ser inversamente proporcional à do paciente e/ou acompanhante. Quanto mais o indígena mostra disposiçâao e/ou desenvoltura em se relacionar com a equipe médica, menos o técnico tende a se expressar, restringindo sua participação a informaçôes sobre medicação ou resultados prévios de exames e consultas, mediante a apresentação do prontuário do paciente. Há também técnicos que não apenas complementam, mas contrariam informaçóes do paciente/acompanhante, desautorizando-o. Como exemplo, uma técnica comentou comigo e sua colega que, durante a consulta de um menino Guarani acompanhado de sua mãe, esta disse que alimentava o filho seis vezes ao dia, "mingau de manhä, frutinha no meio da manhä... enfim, seis refeiçôes. Tive que dizer que era mentira" (Macedo, 2017b).

A seu turno, há casos de especialistas em que a condiçâo indígena do paciente desperta ou amplia o interesse de ver além do corpo biológico que os dispositivos biomédicos performam, de modo a perguntarem sobre a vida nas aldeias e suas práticas terapêuticas. Sobretudo nos tratamentos que implicam diversas consultas e o acompanhamento de um mesmo médico, frequentemente vínculos afetivos são estabelecidos entre pacientes indígenas e especialistas.

Mesmo nesses casos, por vezes, a performaçáa de um corpo biológico implica divergência ou advertência em relação aos corpos constituídos por práticas de conhecimento indígenas. Por exemplo, uma menina Kokama de cerca de dez anos chegou à Casai sem diagnóstico relativo a seus sintomas, que incluem problemas motores e de formaçáo óssea. Acompanhei uma consulta em que o pediatra fez uma série de perguntas sobre os parentes da menina (que possui um irmão com sintomas semelhantes) e elaborou a hipótese de uma síndrome genética. Quando a síndrome foi confirmada por exames, o médico comentou com o pai da menina: "não éculpa de vocês, mas casar com primos faz com que a doença se manifeste mais facilmente nos filhos" (Macedo, 2016b). $\mathrm{O}$ casamento entre primos cruzados (em que o cônjuge é filho/a da irmã do pai ou do irmão da mãe) é considerado comum e desejado na comunidade em que essa família vivia, mas foi apontado pelo médico como um fator determinante na anomalia.

$\mathrm{Na}$ mesma direção, um Wajāpi diagnosticado com problemas cardíacos estava na Casai como acompanhante de seu filho de oito anos, o qual recebera o mesmo diagnóstico, além de outras pessoas de sua família. Quando perguntei sobre a consulta no cardiologista, ele me fez o seguinte comentário (Macedo, 2017c):

Doutor falou que é parentesco, 'vocês estão casando, é por causa disso', ele falou. Ele também falou que é porque 'vocês moram tudo no mato', por isso tem bastante gente que casa assim na aldeia. O doutor perguntou pra mim: 'você casou sua parente, sua prima?'. Mas, se todo mundo na aldeia 
casa assim, então todo mundo ia ter problema no coração. E só um pouquinho que tem.

Nesse comentário, talvez o Wajâpi tenha sugerido que o médico os visse como animais, ao associar 'viver no mato' com casar de modo impróprio. Mas o Wajāpi recusa essa perspectiva, desvinculando a doença das regras de casamento, pois todo mundo casa assim e só alguns têm problemas cardíacos. Por sua vez, da parte do médico, a humanidade dos Wajápi estava dada por seu corpo biológico, mas sua cultura ganhava contornos como razão da doença. O mesmo se pode dizer do caso referente à síndrome genética da menina Kokama, no qual, mesmo que o médico tenha afirmado 'não é culpa de vocês', a performação de um corpo biológico é concomitante à performação da diferença cultural como nexo causal da doença.

Em outros casos, o oposto se passa. Os médicos atribuem a doença a processos concernentes ao corpo biológico e independentes de quaisquer subjetividades, costumes ou comportamentos. Mas muitos indígenas reconhecem seu adoecimento como efeito de algo que tenham feito ou que lhes tenham feito. Um exemplo é o caso de uma menina no Alto Xingu que nasceu com lábio leporino. Essas e outras más formaçóes do corpo podem ser indicadores de agenciamentos feiticeiros ou represálias de outros seres a algo que os pais ou pessoas próximas tenham feito. Os corpos nos quais incidem e se expressam essas inimizades dificilmente podem ser aparentados (portanto humanizados) e participarem da vida na aldeia. Por isso cada vez mais se tem recorrido à medicina dos brancos para corrigir más formaçôes.

No caso dessa menina, uma enfermeira comentou que "a expectativa de seus pais é que ela fechasse a fenda e voltasse bonitinha para a aldeia" (Macedo, 2016c). Ela estava preocupada com a recepçáo da menina na comunidade porque o processo implica algumas cirurgias em tempos espaçados, e a primeira intervenção não tinha corrigido plenamente a má formação. $\mathrm{O}$ pai da menina receava que sua filha nascera assim por algo que ele ou sua esposa fizeram. A equipe de saúde buscou então convencê-lo de que ele não tinha qualquer responsabilidade pelo problema da filha, explicando os processos biológicos que incorrem no lábio leporino. Porém, o doente nunca é totalmente inocentado do que lhe acontece - esta observação de Garnelo (2003, p. 65) sobre os Baniwa pode ser estendida ao Alto Xingu e a muitas socialidades indígenas. Assim como o cuidado pode ser provocado por aquele que o recebe, em muitos casos, o adoecimento não corresponde a uma posição passiva de vítima de uma agressão, e sim a uma retaliação, uma agressão em resposta a outra.

Muitos pacientes buscam na medicina dos brancos a reparação, mesmo que parcial, do corpo numa forma que seja reconhecida por seus parentes. Mas na Casai também experimentam transformaçóes em seus corpos para além das intervenções médicas, como por aquilo que comem, as pessoas, lugares e coisas com que passam a conviver na cidade. $\mathrm{E}$ tais transformaçôes náo raro incidem no modo de ser reconhecido pelos parentes na volta à aldeia, ou de reconhecê-los, sobretudo entre aqueles que ficam por longos períodos. As crianças, particularmente, podem encontrar dificuldade para se familiarizarem novamente com as comidas, espaços e atividades cotidianas junto aos parentes. Uma avó Yudjá, quando veio pela segunda vez acompanhar seu neto em tratamento cardíaco, comentou que ele passou a rejeitar a comida da aldeia quando voltou de uma estadia de oito meses na Casai, e que ela tinha receio que isso ocorresse de novo. Por isso ela não queria que oferecessem leite escuro (acrescido de chocolate), pão de queijo e alimentos que não existem na aldeia.

Seja como for, os corpos nas comunidades também estão continuamente sob intervenção, de modo a construir e reiterar o parentesco daqueles que vivem juntos. $\mathrm{Na}$ Casai, outros modos de intervenção alteram os corpos e podem produzir outros aparentamentos e suas transformaçóes.

\section{Nota final (com prognóstico incerto)}

Ao centrar foco em relaçóes entre pacientes ou acompanhantes indígenas e profissionais de saúde, o artigo buscou o que Mol e Law (2002, p. 11) chamaram de complexidades na escrita etnográfica, voltando-se para coexistências de diferentes mundos, em que coisas se relacionam sem se somarem, ou sem seguirem uma ordem linear ou unívoca. O desafio é definir trilhas e procedimentos, discriminando quais simplificações a 
que vamos recorrer para estabelecer o que deixamos como pano de fundo e para o que voltamos nossa atenção, engendrando assim novas complexidades. Como as conexóes parciais strathernianas, trata-se de uma proposta para o tratamento de textos, mas posso reconhecê-la nos tratamentos de corpos envolvendo meus interlocutores indígenas e profissionais da saúde.

Ainda com Mol e Law (2004), o corpo sob certo tratamento faz (enacts) a doença dando-lhe uma forma, e a doença também faz (enacts) o corpo de um modo específico. Instituiçóes de saúde indígena, particularmente, constituem lugares de incerteza, vulnerabilidade e instabilidade ontológica. Por isso são também lugares de experimentação, em que corpos e doenças ganham formas novas, persuasivas e mutáveis (Street, 2014). As redes do cuidado podem ser ali pensadas no duplo sentido das relaçôes que engendram e de suas formas de captura.

Particularmente, o olhar clínico pode ser um modo de captura em tipologias do normal e do patológico, como apontou Foucault (1999). Porém, retomando o que disse Karai Tataendy, nos mundos ameríndios tudo não é normal. $\mathrm{Na}$ Casai, os indígenas com quem convivi estavam menos dispostos a incorporar ou compartilhar nexos causais dos adoecimentos com os profissionais de saúde do que "na experimentação pragmática com tecnologias relacionais no hospital e na aldeia" (Street, 2014, p.23). A humanização pode figurar entre essas tecnologias relacionais, produzindo vínculos e ampliando capacidades agentivas entre profissionais e pacientes. Mas, assim como o adoecimento, o cuidado é potencialmente uma forma de captura - daí o desafio sempre posto de modular seus efeitos transformativos. É preciso que os médicos vejam a doença em uma forma na qual possam tratá-la, mas a produçáo de opacidade também pode ser necessária nesses espaços de extrema vulnerabilidade, de modo a elicitar o olhar dos brancos sem ser capturado por sua perspectiva. Nesse espaço heterotópico em que se está entre muitos, entre muitos mundos, o corpo é justamente o lugar da diferença e das conexóes possíveis.

\section{Agradecimentos}

A pesquisa a partir da qual este artigo foi escrito foi aprovada na Plataforma Brasil e contou com apoio financeiro do Cnpq (Processo 461089/2014-9). Tratase de um texto inédito redigido durante o período de onze meses, em 2019, em que estive vinculada ao Berkeley Center for Social Medicine da Universidade da Califórnia - Berkeley, com Bolsa de Pesquisa no Exterior (BPE) da Fapesp (Processo 2018/06164-9). Agradeço a essas instituiçóes pelo apoio e acolhimento, assim como sou imensamente grata às equipes da Casai-SP, do Ambulatório do Índio e aos interlocutores indígenas que se dispuseram a compartilhar suas experiências e reflexōes. Também agradeço o apoio e a interlocução do Centro de Estudos Ameríndios - CEstA/USP e do Centro de Pesquisas em Etnologia Indígena - Cpei/ Unicamp, aos quais sou associada. Eximindo-os de qualquer responsabilidade por eventuais equívocos deste texto, agradeço ainda a leitura e os importantes apontamentos de Aline Regitano (CEstA-USP), Bru Pereira (AnCA-Unifesp), Eduardo Soares Nunes (Ufopa), Maria Christina Barra (PPGAS-UFMG), Maria Cristina Troncarelli (Projeto Xingu-Unifesp), Rodrigo Brusco (CEstA-USP) e pareceristas da RBCS.

\section{Notas}

1 Strathern (1991) propóe conexóes parciais como recurso metodológico, pelo qual campos etnográficos ou teóricos (a exemplo de antropologia e feminismo na obra da autora) podem inserir diferença uns nos outros, de modo a ampliar possibilidades reflexivas, agentivas e compositivas, prescindindo de comparaçóes holísticas ou funcionalistas.

2 Segundo página do Ministério da Saúde: https://www. saude.gov.br/noticias/sesai/14600-casais-ministerio-dasaude-quer-aprimorar-casas-de-apoio-a-saude-indígena, acessado em 8/8/2019.

3 Em 2017, o quadro de funcionários da Casai-SP contava com um chefe administrativo, cinco enfermeiros, uma responsável técnica de enfermagem, 22 técnicos de enfermagem, uma farmacêutica, uma assistente Social, uma psicóloga, um nutricionista, três servidores públicos (setor administrativo), quatro seguranças, cinco faxineiras, duas cozinheiras, dois auxiliares de cozinha e oito motoristas (Barbeiro, 2017, p.16).

4 Experiências e concepçóes de adoecimento entre diferentes povos indígenas são densamente tematizadas na literatura etnológica (por ex. Gallois, 1988; Buchillet, 2002; Garnelo, 2003; Barcelos Neto, 2006; Kopenawa e Albert, 2015; Martín, 2015; Araújo, 2015; Rosalen, 2008, 2017). 
5 Mol se vale predominantemente da expressáo enact, de difícil tradução para o português. Ela comenta que se pode dizer que uma doença é performada (performed), na medida em que é feita (done) por práticas, dispositivos e relaçóes - mas ressalva que não se trata de performance no sentido de desempenho tampouco de representação (2002, p.32). A despeito de não serem usuais na língua portuguesa, recorro a expressóes como performada e performaçâao para me aproximar do sentido de enacted ou enact ao longo do texto. Usei também os verbos realizar e fazer como traduçóes de enact.

6 Buscando evitar exposiçóes indevidas, os nomes de meus interlocutores na pesquisa são omitidos.

7 Vários trabalhos destacam a centralidade da alimentação na experiência e nas demandas dos indígenas em Casais, a exemplo de Gonçalves (2011) e Guimaraes e Rosa (2019). Dias da Silva (2010, p. 31) comenta que na Casai de Jacareanga (PA) os Munduruku exigem que os cozinheiros sejam de seu povo, pois "desconfiavam dos brancos para preparar os alimentos dos doentes e alegavam que estes não entendiam algumas restriçóes alimentares seguidas tanto por gestantes, homens em resguardo por seus bebês recém-nascidos e doentes".

8 As citaçóes relativas ao trabalho de campo ao longo do artigo foram adequadas ao modelo proposto pela RBCS. A referência à minha autoria é um modo de preservar o sigilo da identidade de meus interlocutores fazendo referência a meu caderno de campo, onde as falas foram anotadas.

9 Os nomes foram aqui trocados.

10 Sobre a retórica pedagógica ou "compreensiva" entre profissionais de saúde, em materiais impressos sobre doenças e prevenção ou em manuais voltados para agentes indígenas de saúde, como estratégias de intervenção biomédica e desqualificação de práticas de conhecimento indígenas, ver por exemplo Dias da Silva (2010), Novo (2010) e Teixeira e Dias da Silva (2015).

11 Trabalhando inicialmente na Terra Indígena do Xingu, posteriormente o Projeto Xingu foi expandindo sua área de atuação, sendo hoje uma das principais referências no campo da saúde indígena. [http://www.projetoxingu. unifesp.br, acessado em 08/082019]; ver também Assumpção (2014).

12 Sobre o Ambulatório do Índio: http://www.projetoxingu. unifesp.br/index.php/ambulatorio-do-indio/sobreo-ambulatorio, acessado em 8/8/2019; ver também Assumpção (2014) e Pereira (2012). Segundo Assumpção (2014, p.141), em 2014, o ambulatório contava com dois médicos (um pediatra e um clínico geral/cardiologista), duas enfermeiras, uma auxiliar de enfermagem e uma auxiliar administrativa. Essa configuração variou entre 2015 e 2018, quando frequentei o local. Sobre o convênio estabelecido entre a Casai-SP e o Hospital Sáo Paulo, ver Gonçalves (2011, p.34).

13 Ver: http://www.projetoxingu.unifesp.br/index.php/ ambulatorio-do-indio/sobre-o-ambulatorio, acessado em 8/8/2019.

14 Como as comunidades alto-xinguanas são pequenas e as pessoas facilmente reconhecíveis, por vezes, não menciono o povo para evitar exposiçōes indevidas.

15 Sobre conceituaçôes guarani de $n h e e e ̂$, ver por exemplo Macedo e Sztutman (2014).

16 Na mesma direção, Gonçalves (2011, p. 60) comenta a fala de um Kapinawa, em 2005, que dizia ter pego açúcar no sangue durante o mês que estava na Casai devido à alimentação.

\section{REFERÊNCIAS}

ARAÚJO, Íris Moraes. (2015), Osikirip: os 'especiais' Karitiana e a noção de pessoa ameríndia. Tese de Doutorado, PPGAS-USP, São Paulo.

ASSUMPÇÃO, Karine. (2014), Negociando curas: um estudo das relaçóes entre profissionais de saúde nãoindigenas e indigenas no Projeto Xingu. Dissertação de Mestrado, PPGCS-Unifesp, Guarulhos.

AYRES, José Ricardo C. M. (2006), "Cuidado e humanização das práticas de saúde”, in S.F. Deslandes (org), Humanização dos cuidados em saúde: conceitos, dilemas e práticas, Rio de Janeiro, Fiocruz.

BARBEIRO, Gláucio. (2017), Opovo Guarani e sua cosmovisão relacionada a concepção de saúde. TCC em Especialização em Saúde Indígena-Unifesp, São Paulo.

BARCELOS NETO, Aristóteles. (2006), “'Doença de Índio’: o princípio patogênico da alteridade e os modos de transformação de uma cosmologia amazônica”. Campos, 7, 1: 09-34. DOI: http:// dx.doi.org/10.5380/cam.v7i1.5451

BONILLA, Oiara. (2005), "O bom patrão e o inimigo voraz: predação e comércio na cosmologia Paumari." Mana, 11, 1: 41-66. DOI: https:// doi.org/10.1590/S0104-93132005000100002.

BUCHILLET, Dominique. (2002), "Contas de vidro, enfeites de branco e 'potes de malária'. Epidemiologia e representaçóes de doenças infecciosas entre os Desana do Alto Rio Negro", 
in B. Albert \& A. Ramos (org), Pacificando o branco: cosmologias do contato no norte-amazônico, Sáo Paulo, Unesp, Imprensa Oficial do Estado. BUCHILLET, Dominique. (2004), "Cultura e saúde pública: reflexôes sobre o Distrito Sanitário Especial Indígena do Rio Negro", in E.J. Langdon \& L. Garnelo, Saúde dos povos indígenas: reflexóes sobre antropologia participativa, Rio de Janeiro, ABA, Contracapa.

CALDEIRA, Vanessa. (2010), "Programa Tamoromu: uma experiência em promoção de saúde indígena e prática interdisciplinar na Casai-SP”, in Conselho Regional de Psicologia 6a Regiāo (org.), Psicologia e Povos Indígenas, São Paulo, CRPSP.

CARDOSO, Marina. (2014), "Saúde e povos indígenas no Brasil: notas sobre alguns temas equívocos na política atual". Cadernos de Saúde Pública 30, 4: 860-866. DOI: https://doi.org/10.1590/0102311 X00027814.

CRUZ, Luiza G.M.M. \& GUIMARĀES, Silvia. (2016), "Hospitalização de pacientes indígenas no DF/Brasil", in F. Asensi et al. (org), Saúde e direitos humanos, Rio de Janeiro, Multifoco.

DESLANDES, Suely F. (org). (2006), Humanização dos cuidados em saúde: conceitos, dilemas e práticas, Rio de Janeiro, Fiocruz.

DIAS DA SILVA, Cristina. (2010), “Cotidiano, saúde e política. Uma etnografia dos profissionais da saúde indígena." Tese de Doutorado, PPGASUnB, Brasília.

FAUSTO, Carlos. (2008), "Donos demais: maestria e domínio na Amazônia”. Mana, 14, 2: 32966. DOI: https://doi.org/10.1590/S010493132008000200003.

FOUCAULT, Michael. (1977), O nascimento da clínica, Rio de Janeiro, Forense Universitária.

FOUCAULT, Michael. (2013), O corpo utópico, as heterotopias, São Paulo, N-1 Edições.

FOUCAULT, Michael. (1999), História da sexualidade 1: a vontade de saber, Rio de Janeiro, Graal.

GALLOIS, Dominique T. (1988). Movimento na cosmologia waiäpi: criação, expansão e transformação do universo". Tese de Doutorado, PPGAS-USP, São Paulo.
GALLOIS, Dominique T. (1991), "A categoria 'doença de branco': ruptura ou adaptação de um modelo etiológico indígena?”, in D. Buichillet (org). Medicinas tradicionais e medicina ocidental na Amazônia, Belém, Cejup.

GARFUNKEL, Joana. (2010), "Promoção da saúde mental indígena. A experiência da Casai-SP", in Conselho Regional de Psicologia 6a Regiáo (org.), Psicologia e Povos Indígenas, São Paulo, CRPSP.

GARNELO, Luisa. (2003), Poder, hierarquia e reciprocidade: saúde e harmonia entre os Baniwa do Alto Rio Negro, Rio de Janeiro, Fiocruz.

GOFFMAN, Erving. (1974), Manicômios, Prisóes e Conventos, São Paulo, Perspectiva.

GONÇALVES, Lucila J. M. (2011), Na fronteira das relaçóes de cuidado em saúde indígena, São Paulo, Annablume.

GOOD, Byron J. (1993), Medicine, rationality and experience: an anthropological perspective. Cambridge, Core.

GUIMARÁES, Silvia \& ROSA, Jéssica C.S.R. (2019). "Saúde indígena e democracia no Brasil a partir de uma abordagem antropológica”, in L.O. Xavier et al.(org), A qualidade da democracia no Brasil: questóes teóricas e metodológicas da pesquisa, Curitiba, CVR.

HALPERN, Jordi. (2001), From detached concern to empathy: humanizing medical practice, New York, Oxford University Press.

KELLY, José Antônio \& MATOS, Marcos A. (2019), "Política da consideração: ação e influência nas terras baixas da América do Sul". Mana, 25, 2: 391-426. DOI: https://doi.org/10.1590/167849442019v25n2p391

KOPENAWA, Davi \& ALBERT, Bruce. (2015), A queda do céu: palavras de um xamá yanomami, São Paulo, Companhia das Letras.

LANGDON, Esther Jean. (1991), "Percepção e utilização da medicina ocidental pelos índios Sibundoy e Siona no sul da Colômbia”, in D. Buchillet (org). Medicinas tradicionais e medicina ocidental na Amazônia, Belém, Cejup.

LANGDON, Esther Jean \& GARNELO, Luisa (org). (2004), Saúde dos povos indigenas: reflexóes 
sobre antropologia participativa, Rio de Janeiro, Contracapa, ABA.

LANGDON, Esther Jean \& GARNELO, Luisa (2017), "Articulación entre servicios de salud y 'medicina indígena': reflexiones antropológicas sobre política y realidad en Brasil". Salud Colectiva, 13, 3: 457-470. DOI: https://doi.org/10.18294/ sc.2017.1117.

MACEDO, Valéria. (2013), "De encontros nos corpos guarani". Ilha - Revista de Antropologia, 15, 1: 181-210. DOI: https://doi.org/10.5007/21758034.2013v15n1-2p180.

MACEDO, Valéria. (2017), "Misturar e circular em modulaçôes guarani. Uma etiologia das (in) disposições". Mana 23, 3: 511-543. DOI: https:// doi.org/10.1590/1678-49442017v23n3p511.

MACEDO, Valéria. (2019), “'Alimento morto' e os donos na cidade: comensalidade e alteridade em uma aldeia guarani em São Paulo". Etnográfica, 23, 3: 605-625. DOI: https://doi.org/10.4000/ etnografica. 7247 .

MACEDO, Valéria \& SZTUTMAN, Renato. (2014), "A parte de que se é parte. Notas sobre individuação e divinização (a partir dos Guarani)". Cadernos de Campo, 23, 1: 287-302. DOI: https://doi. org/10.11606/issn.2316-9133.v23i23p287-302

MACEDO, Valéria; MARTINS, Jaciara Augusto \& TRONCARELLI, Maria Cristina. (2017), "Três linhas e alguns nós: serviço social, educação e Antropologia na CASAI-SP". Amazônica - Revista de Antropologia, 9, 2: 632-659. DOI: http:// dx.doi.org/10.18542/amazonica.v9i2.5668

MARTÍN, Johana. (2015), "Healing in the hospital: the caring sensorium and the containment of Yanomami bodies". Tipiti, 13, 2: 120-135.

MERHY, Emerson. (1997), "O SUS e um dos seus dilemas: mudar a gestão e a lógica do processo de trabalho em saúde (um ensaio sobre a micropolítica do trabalho vivo)", in S. Fleury (org), Saúde e democracia: a luta do CEBES, São Paulo, Lemos.

MOL, Annemarie. (2002), The body multiple: ontology in medical practice, Durham \& London, Duke University Press.
MOL, Annemarie. (2008), The logic of care. Health and the problem of patient choice, New York, Routledge.

MOL, Annemarie \& LAW, John. (2002), "Complexities: an introduction", in A. Mol \& J. Law, Complexities: social studies of knowledge practices, Durham \& London, Duke University Press.

MOL, Annemarie \& LAW, John. (2004), "Embodied action, enacted bodies. The example of hypoglycaemia". Body \& Society, 10, 2-3: 43-62.

NOVO, Marina. (2010), Os agentes indigenas de saúde do Alto Xingu, Brasília, Paralelo15.

NUNES, Eduardo S. (2013), "O território das onças e a aldeia dos brancos: lugar e perspectiva entre os Karajá de Buridina". Journal de la Société des américanistes 99, 2: 35-64. DOI: https://doi. org/10.4000/jsa. 12889.

PEREIRA, Pedro Paulo. (2012), "Limites, traduçôes e afetos: profissionais de saúde em contextos indígenas". Mana 18, 3: 511-38. DOI: http:// dx.doi.org/10.1590/S0104-93132012000300004

ROSALEN, Juliana. (2017), Tarja preta: um estudo antropológico sobre estados alterados' diagnosticados pela biomedicina como transtornos mentais nos Wajāpi do Amapari. Tese de Doutorado, PPGASUSP, São Paulo.

ROSALEN, Juliana (2008), Aproximaçóes à temática das DST aos Wajäpi do Amapari. Dissertação de Mestrado. PPGAS-USP, São Paulo.

SPINOZA, Benedictus. (2013 [1677]), Ética, Belo Horizonte, Autêntica.

STARFIELD, Bárbara. (2004), Atenção primária: equilibrio entre necessidades de saúde, serviços e tecnologia, Brasília, Unesco, Ministério da Saúde.

STENGERS, Isabelle. (2007), "La proposition cosmopolitique", in I. Stengers, L'émergence des cosmopolitiques, Paris, Éditions La Découverte.

STRATHERN, Marilyn. (1991), Partial connections, Lanham, AltaMira Press.

STRATHERN, Marilyn. (2006), O gênero da dádiva: problemas com as mulheres e problemas com a sociedade na Melanésia, Campinas, Unicamp.

STREET, Alice. (2014), Biomedicine in an unstable place, Durham \& London, Duke University Press. 
TEIXEIRA, Carla Costa \& DIAS DA SILVA, Cristina. (2015), "The construction of citizenship and the field of indigenous health: a critical analysis of the relationship between bio-power and bioidentity", Vibrant, 12, 1: 351-84. DOI: http:// dx.doi.org/10.1590/1809-43412015v12n1p351.

TEIXEIRA, Ricardo. (2003), “O acolhimento num serviço de saúde entendido como uma rede de conversações", In R. Pinheiro; R.A. Mattos (org). Integralidade: cotidiano, saberes e práticas em saúde, Rio de Janeiro, IMS/Uerj, Abrasco.

VIVEIROS DE CASTRO, Eduardo. (2002), "Perspectivismo e multinaturalismo na América Indígena”, in E. Viveiros de Castro, A inconstância da alma selvagem e outros ensaios de antropologia, São Paulo, Cosac Naify.

VIVEIROS DE CASTRO, Eduardo. (2007), "Filiação intensiva e aliança demoníaca". Novos Estudos, 77, 1: 91-126. DOI: http://dx.doi.org/10.1590/ S0101-33002007000100006.

\section{CITAÇÓES DO TRABALHO DE CAMPO:}

MACEDO, Valéria. (2015), Fala de uma acompanhante indígena de paciente (identidade preservada) registrada em caderno de campo, 04/2015, Casai, São Paulo.

MACEDO, Valéria. (2015a), Fala de uma enfermeira (identidade preservada) registrada em caderno de campo durante oficina de capacitação da equipe da Casai-SP ministrada pela equipe do Projeto Xingu, 05/2015, Projeto Xingu, São Paulo.

MACEDO, Valéria. (2016), Fala de uma técnica em enfermagem (identidade preservada) registrada em caderno de campo, 09/2016, Casai, São Paulo.
MACEDO, Valéria. (2016a), Fala de um técnico em enfermagem (identidade preservada) da Casai registrada em caderno de campo, 05/2016, Hospital São Paulo, São Paulo.

MACEDO, Valéria. (2016b), Fala de um médico (identidade preservada do profissional e da instituição) registrada em caderno de campo quando acompanhava um paciente indígena, 09/2016, São Paulo.

MACEDO, Valéria. (2016c), Fala de uma enfermeira (identidade preservada) registrada em caderno de campo, 05/2016, Ambulatório do Índio, São Paulo.

MACEDO, Valéria. (2017a), Fala de uma técnica em enfermagem (identidade preservada) registrada em caderno de campo, 08/2017, Casai, São Paulo.

MACEDO, Valéria. (2017b), Fala de uma técnica em enfermagem (identidade preservada) no translado de carro da Casai-SP para o Hospital Sáo Paulo registrada em caderno de campo, 10/2017, São Paulo.

MACEDO, Valéria. (2017C), Fala de um paciente indígena (identidade preservada) registrada em caderno de campo, 11/2017, Casai, São Paulo.

MACEDO, Valéria. (2018), Fala de uma técnica em enfermagem (identidade preservada) registrada em caderno de campo, 03/2018, Casai, São Paulo.

MACEDO, Valéria. (2018a), Fala de uma técnica em enfermagem (identidade preservada) registrada em caderno de campo, 04/2018, Casai, São Paulo. 


\section{O CUIDADO E SUAS REDES: DOENÇA E DIFERENÇA EM INSTITUIÇÓES DE SAÚDE INDÍGENA EM SÃO PAULO}

\section{Valéria Macedo}

Palavras-chave: cuidado, humanização, saúde indígena, atenção diferenciada, Casai.

Cuidado e humanização são palavras interseccionadas na etnologia ameríndia e, de modo distinto, em abordagens no campo da saúde. Busco estabelecer conexóes parciais entre tais campos como modo de fazer visíveis algumas questóes relativas à minha experiência etnográfica na Casai (Casa de Apoio à Saúde Indígena) em Sáo Paulo. Para muitos indígenas, esse espaço pleno de diferença intensifica a vulnerabilidade e efeitos transformacionais inerentes ao adoecimento. Estar sob cuidado de nãoindígenas constitui um ponto convergente entre pessoas de diferentes povos que vêm a Sáo Paulo para tratamento biomédico. Ser alvo de cuidado implica estar sob o olhar - e, portanto, a consideração ou intervenção - de outrem, mas implica também fazer-se visível a ele, mobilizando-o de modos específicos. Este artigo se volta para algumas relaçóes de cuidado em que pacientes indígenas e profissionais de saúde estấo ativamente, $\mathrm{e}$ diferentemente, implicados.

\section{CARE AND ITS NETWORKS: DISEASE AND DIFFERENCE IN INDIGENOUS HEALTH INSTITUTIONS IN SÃO PAULO}

\section{Valéria Macedo}

Keywords: care, humanization, indigenous health, differentiated care, Casai.

Care and humanization are intersecting words in Amerindian ethnology and, in distinct ways, in the Healthcare field. I attempt to establish partial connections between such fields as a way to make some issues related to my ethnographic experience at Casai (Casa de Apoio à Saúde Indígena), in São Paulo, visible. For many indigenous people, this space crossed by differences intensifies the vulnerability and transformational effects inherent to illness. Being under the care of non-indigenous people is a convergence point between individuals from different peoples who come to Sáo Paulo for biomedical treatment. Being a target of care implies being under the eyes - and, therefore, the consideration or intervention - of others, but also implies in making yourself visible to them, mobilizing them in specific ways. This article focuses on some care relationships in which indigenous patients and health professionals are actively, and differentially, involved.

\section{LE SOIN ET SES RÉSEAUX: MALADIE ET DIFFERENCE DANS LES INSTITUTIONS DE SANTE POUR LES AMERINDIENS À SÁO PAULO}

\section{Valéria Macedo}

Mots-clés: soin; santé des Amérindiens; attention différenciée; Casai.

Soin et humanisation sont des termes interreliés dans l'ethnologie amérindienne et, de manière distincte, dans les approches du domaine de la santé. Ce travail vise à établir des connexions partiels entre ces domaines afin de mettre en évidence des questions relatives à mon expérience ethnographique au sein de la Casai (Casa de Apoio à Saude Indígena) de São Paulo. Pour beaucoup d'Amérindiens, cet espace traversé par la différence intensifie la vulnérabilité et les effets transformateurs inhérents à la maladie. Être aux soins des non-amérindiens est un point convergent entre les personnes de différents peuples qui viennent à São Paulo pour les traitements biomédicaux. Être soigné signifie être sous le regard - et donc considéré et pris en charge - d'autrui, mais aussi être visible pour lui et le mobiliser de diverses manières. Cet article se concentre sur certaines relations de soins où les patients amérindiens et les professionnels de santé sont activement, et diversement, impliqués. 